\title{
Behavioural and physiological adaptation of wild ruminants and their potential for meat production
}

\section{By J. H. Topps, School of Agriculture, University of Aberdeen, 58I King Street, Aberdeen $A B 9$ I $U D$}

Harvesting of wild ruminants occurs to an appreciable extent in several countries, but the potential world production of meat from these animals is greatly in excess of the current yield. Any increase in the utilization of this important source of protein may be obtained by either an increase in the cropping of present animal systems or through the introduction of changes such as those imposed by ranching or farming. To choose the course of action with the greatest chance of success it is necessary to examine the knowledge available on the nutritional physiology and carcass characteristics of wild ruminants. In such an examination it is important to remember that game animals should be considered as complementary to and not competitive with domestic livestock for two major reasons. Many of them can thrive either in hot arid areas that lack sufficient water and suitable grazing for domestic livestock or in very cold parts of the world where the winter conditions are too adverse for farming or ranching. Secondly, in less marginal regions wild ruminants may be needed to increase the total carrying capacity or to control bush encroachment by eating a part of the vegetation, i.e. shrubs and trees, not normally consumed by domestic livestock. The physiological and behavioural characteristics that enable some ruminants to complement their domestic counterparts are therefore of considerable importance and interest.

\section{Food preferences}

A large number of estimates have been made of the food preferences of wild ruminants using one or more of the techniques available for such studies. Unfortunately all the methods are liable to considerable error or bias. Visual observation of wild ruminants is probably the most commonly employed technique and it is particularly useful for browsers and mixed feeders. Besides the obvious difficulty in gaining close proximity for accurate observation there are other limitations, such as that the preferences of nocturnal feeders cannot be estimated and that observations need to be considered over long periods and are very time-consuming. To overcome some of these difficulties tame animals have been used by some people (e.g. Field, 1968). This method has an additional advantage in that samples, even of plant parts, can be taken for chemical analysis. Unfortunately there are serious doubts about the similarity of food preferences of a tame ruminant to those of the same wild species. If the tame animal has been reared from a young age on an artificial diet, any similarity in preference is likely to be purely incidental. In addition, the habits of a 
single animal or a few animals may be different from those of animals in large groups or herds.

To avoid some of these pitfalls some researchers have resorted to the use of the indirect methods of stomach or faecal analysis. Stomach analysis requires the killing of representative animals, which is rarely done to obtain only stomach samples, and to be of any value many samples are required, particularly when a quantitative study based on frequency is conducted. The technique has been used with considerable success for the macroscopic identification of dicotyledons (Wilson \& Child, 1964, 1965; Wilson, 1965, 1966, 1969). With grasses, microscopic identification must be made, but it is possible to determine on an approximate weight basis the relative amounts of browse and grass eaten by the animal (Azavedo \& Agnew, 1968). Stomach analysis has one advantage over faecal analysis; it avoids the complication of selective digestion of different plants in the lower gut. The faecal analysis technique was developed and used, however, to obviate the need to slaughter animals. Stewart (1967) carried out the original work on the microscopical analysis for epidermal fragments of leaf blades of grasses in the faeces. Kiley (1966) showed that with waterbuck (Kobus ellipsiprymnus) it can give useful results, but it is now known that intraspecies variation may occur in specimens growing in different areas, and differences between species in stem cuticle may be too little for identification (Field, 1968).

Food preferences of wild ruminants have been shown to be influenced by season (Boeker, Scott, Reynolds \& Donaldson, 1972), district or area (Mitchell \& Smoliak, 1971), presence of other species (Jarman, 1971) density of stocking (Nellis \& Ross, 1969) and age of the animal (Field, 1968). Because of these numerous variations and the absence of critical information on voluntary intake of vegetation, measurements of food preferences have very limited nutritional value. They are far more useful to ecologists and conservationists. Three important nutritional factors have evolved, however, from published results on food preferences of wild ruminants. Some species like the eland (Taurotragus oryx) and giraffe (Giraffa camelopardalis) are mainly browsers, which make them suitable for use with cattle or sheep which are predominantly grazers. The diet of wild ruminants can be extraordinary varied: as many as sixty plant species have been identified as being eaten in one period by one species. Such a wide variety is likely to provide some insurance against the occurrence of nutrient deficiencies. Thirdly, the results of chemical analysis indicate that the vegetation selected is of medium to high quality. For example, Roth \& Osterberg (1971) have found that the crude protein contents of dry matter of vegetation selected by eland ranged from 80 to $230 \mathrm{~g} / \mathrm{kg}$. If this phenomenon is widespread then it is likely that when wild ruminants are undergoing a period of poor nutrition it may be due to insufficient energy and not to a combined deficiency of energy and protein, which is common in domestic ruminants grazing mature dry herbage.

\section{Regulation of heat losses and requirement for water}

The water requirements of ruminants are closely associated with their feeding habits and their ability to live in dry regions. It is well known that species such as 
the oryx (Oryx gazella) and Grant's gazelle (Gazella granti) are able to thrive without frequent access to free water in hot regions where there is intense solar radiation, e.g. northern Kenya. This is a particularly important characteristic since such animals do not need to congregate and feed in the vicinity of water holes, and cause severe denudation of the vegetation and soil erosion. The apparently very low water requirement of such animals has been explained by the work of Taylor and his colleagues in East Africa. If the oryx is given restricted amounts of water and becomes dehydrated, exposure to an ambient temperature of $45^{\circ}$ causes its body temperature to rise to at least this temperature without any distress to the animal (Taylor, 1969). When conditions become cooler, the body temperature returns to normal. This capacity to store heat is equivalent to a substantial saving of water used in evaporative cooling and is called adaptive hyperthermia. When fully hydrated, the oryx shows little or no fluctuation in body temperature. Taylor \& Lyman (1967) have recorded a wide variation in the body temperature of the eland, from 34 to $42^{\circ}$, but dehydration was not a prerequisite for the adaptive hyperthermia. The phenomenon has not been found in all wild ruminants which appear to withstand a high solar radiation load, the wildebeest (Connochaetes taurinus) being a notable exception.

Since desert animals like the camel have the capacity to greatly concentrate their urine and reduce this water loss (Schmidt-Nielsen, 1964), the same characteristic was thought to occur in ruminants adapted to dry areas. Rather surprisingly such an ability is not pronounced and the renal efficiency of the oryx and the eland may be described as moderately high (Taylor \& Lyman, 1967). It is interesting to speculate that this mediocre renal function may be related to a high urinary excretion of urea arising from corresponding dietary protein intakes. Arman (1969) has shown that eland on the same range as cattle have about twice the protein intake. Some water is conserved by wild ruminants when dehydrated through the production of dry faeces (Taylor \& Lyman, 1967; Taylor, 1969), but the reduction may be small when compared with that of domestic animals because in hot areas wild ruminants are likely to have both a higher intake of food and output of faecal dry matter.

It is surprising that some wild ruminants that are adapted to hot dry regions exhibit evaporative cooling by increased respiration, which involves an additional energy expenditure higher than that needed for sweating. The wildebeest and oryx are interesting subjects for study in this respect (Taylor, 1969; Taylor, Robertshaw \& Hofmann, 1969). When oryx sustain a body temperature of $45^{\circ}$ for several $h$, it might be expected that brain tissue would be damaged. To avoid this happening it is conceivable that respiratory evaporation causes the venous blood returning from the nasal sinuses to be considerably cooler than the arterial blood in the carotid arteries. Consequently in the cavernous sinus an opportunity exists for counter-current heat exchange between the cool venous blood and warmer arterial blood before the arterial blood reaches the brain. Although wildebeest maintain body temperature relatively constant by panting, respiratory alkalosis does not develop until air temperatures approach $50^{\circ}$. This maintenance of acid-base balance may be due to a larger effective dead space during panting, an increase contributed by larger nasal passages and openings into the paranasal sinuses. All these and other physio- 
Table I. Minimum water requirements ( $\mathrm{g} / \mathrm{kg}$ body-weight) of various domestic and voild ruminants exposed to $40^{\circ}$ during the day and $22^{\circ}$ at night (after Taylor, 1968a).

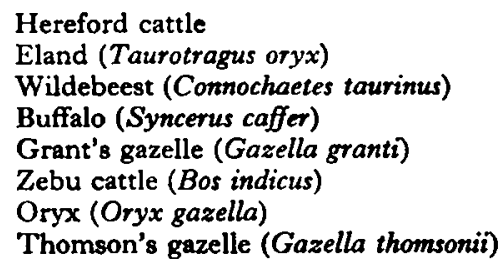

$$
\begin{aligned}
& 64 \cdot 2 \\
& 54 \cdot 9 \\
& 48 \cdot 1 \\
& 45 \cdot 8 \\
& 38 \cdot 6 \\
& 32 \cdot 2 \\
& 30 \cdot 0 \\
& 27 \cdot 4
\end{aligned}
$$

logical stratagems are responsible for the physiological adaptation of wild ruminants to hot, arid environments and are reflected to some extent in the minimum water requirements of different species (see Table $\mathbf{r}$ ).

However, there are some inconsistencies between water requirements and the ability to thrive under arid conditions which have been explained by the food preferences of particular species. Eland, for example, have higher water requirements than zebu cattle (Bos indicus) but they habitually select browse with a higher water content than that of the grasses. A more pronounced situation has been highlighted by Taylor (1968b) who showed that a species of Disperma shrub favoured by oryx and Grant's gazelle was capable of gaining water from the atmosphere at temperatures and humidities which frequently prevail at night. For example at $17^{\circ}$ and $85 \%$ relative humidity, Disperma leaves contained more than $40 \%$ water. This hygroscopic water, together with metabolic water from the leaves, may be sufficient to meet the minimum water requirements of oryx and Grant's gazelle.

\section{Reproductive performance}

An important part of the productivity of wild ruminants is their reproductive performance under natural conditions. Unfortunately the published results on this subject are comprehensive for only a few species. Nevertheless, African ruminants such as buffalo (Syncerus caffer), wildebeest and impala (Aepyceros melampus) are among those animals that are becoming over-abundant in several areas where hunting is prevented. Such increases are dependent on a low level of predation but they also strongly indicate that the rate of reproduction is high and the life-span is long. For example, Talbot \& Talbot ( $\mathrm{r}_{963}$ ) have found that wildebeest heifers mate during their second year and calve at 2 years with an $83 \%$ calving percentage. Mature females have a calving percentage of $95 \%$ and the life-span of the species is about $\mathrm{I} 8$ years. In other studies Skinner, Von la Chevallerie \& Van Zyl (1971) and du Plessis (1972) showed that the springbok (Antidorcas marsupialis) and blesbok (Damaliscus albifrons) reached sexual maturity at a young age and these young animals had a high fertility. Records from these and other animals show that twins are very rare, e.g. one in seventy-four births for the springbok. Several species, e.g. impala, dik-dik (Rhynchotragus guentheri), springbok and Uganda kob (Adenota kob thomasi), show the curious physiological phenomenon of implantation occurring exclusively or almost exclusively in the right horn. Nonetheless the lack of twins does not preclude an annual calving percentage greater than 100 in small ruminants, since two parturitions per year have been recorded in some areas where good conditions prevail. 


\section{Milk production}

The lack of information on the milk yield of wild ruminants is striking and unfortunate. The nervous disposition of these animals prevents complete letdown of milk and at times only very small amounts have been obtained by hand (Skinner et al. 1971). Once animals have become domesticated, they may well be readily trained for milking, as has been achieved with the eland (Treus \& Kravchenko, 1968). Under natural conditions, to obtain a realistic measure of yield it is necessary to use the sucking offspring and either attempt to weigh the animal before and after sucking or use an indirect technique like that derived by MacFarlane, Howard \& Siebert (1969). This latter method, which involves the use of tritiated water to measure water turnover and its relationship with milk intake, provides a convenient way of estimating consumption with little disturbance or stress. McEwan \& Whitehead (197I) have applied the technique successfully to caribou (Rangifer tarandus) calves. Results have been published for the milk composition of a large number of ruminants (see review by Smith, 1970). Because certain samples may not fully represent the milk consumed by the young animal, some comparisons between species may be misleading. Furthermore it is now known that within some species there are likely to be substantial differences between individuals which may be as large as those between species (Topps, unpublished results).

In general the milk of wild ruminants appears to be richer in fat and protein than that of domestic cattle. Reported values for fat content range from 44 to $204 \mathrm{~g} / \mathrm{kg}$ milk and for protein from 29 to $\mathrm{I} 78 \mathrm{~g} / \mathrm{kg}$. The output of milk energy per $\mathrm{kg}$ for some species may be as high as about ro $\mathrm{MJ}$ compared with $3.2 \mathrm{MJ} / \mathrm{kg}$ for conventional cow's milk containing $40 \mathrm{~g}$ butter fat $/ \mathrm{kg}$. A small consumption of such milk may be equivalent to a considerable intake of energy.

\section{Fasting metabolism}

Since wild ruminants frequently experience periods of maintenance or submaintenance nutrition, a knowledge of their fasting metabolism is of considerable relevance and practical importance. Furthermore, its measurement is one means of

Table 2. Fasting metabolism of some wild ruminants ( $k y / k g$ body-weight $t^{0.75}$ per $24 h$ )

\begin{tabular}{|c|c|c|}
\hline Species & $\begin{array}{l}\text { Fasting } \\
\text { metabolism }\end{array}$ & Reference \\
\hline White-tailed deer (Dorcelaphus virginianus) & 284 & Silver, Colovos \& Hayes (1959) \\
\hline Red deer (Cereus elaphus) & $37^{\circ}$ & Brockway \& Maloiy (1968) \\
\hline Young eland (Taurotragus oryx) & 418 & Rogerson (I068) \\
\hline Wildebeest (Connochaetes taurinus) & $392\}$ & \\
\hline $\begin{array}{l}\text { White-tailed deer } \\
\text { Young caribou (Rangifer tarandus) } \\
\text { Pronghorn antelope (Antilocapra americana) } \\
\text { White-tailed deer }\end{array}$ & $\begin{array}{c}293-721 \\
426 \\
385 \\
343-644\end{array}$ & $\begin{array}{l}\text { Silver, Colovos, Holter \& Hayes (1969) } \\
\text { McEwan \& Whitehead (1970) } \\
\text { Wesley, Knox \& Nagy (1970) } \\
\text { Silver, Holter, Colovos \& Hayes (197I) }\end{array}$ \\
\hline Blesbok (Damaliscus albifrons) & 540 & du Plessis (1972) \\
\hline Young white-tailed deer & $322-694 *$ & $\begin{array}{l}\text { Thomipson, Holter, Hayes, Silver \& Urban } \\
\text { (1973) }\end{array}$ \\
\hline $\begin{array}{l}\text { Young pronghorn antelope } \\
\text { Mature pronghorn antelope }\end{array}$ & $\left.\begin{array}{l}489 \\
322\end{array}\right\}$ & Wesley, Knox \& Nagy (1973) \\
\hline
\end{tabular}


estimating energy requirements for maintenance, which are a large overhead in many systems of ruminant production. The values in Table 2 are a summary of the published fasting measurements.

Since the training of animals for these determinations may be difficult, some of the values quoted may be affected by displays of nervous activity. The values as they stand indicate that all the wild ruminants studied had a fasting metabolism higher than the interspecies mean of $293 \mathrm{~kJ} / \mathrm{kg}^{0.75}$ per $24 \mathrm{~h}$. In white-tailed deer very large seasonal variations were noted, the values for the summer months being 50$100 \%$ greater than those in the winter. With the same species, lowering the ambient temperature caused a significant increase in fasting heat production.

\section{Digestibility of food}

Surprisingly few studies have been carried out to compare the digestive ability of wild ruminants with that of cattle or sheep. In general digestion in red deer (Cervus elaphus) and sheep were found to be similar by Kay, Maloiy \& Goodall (1968), but the outflow of liquid from the reticulo-rumen was considerably greater in deer than in sheep even after allowing for any difference in size. The greater flow may account for a lower digestibility of cellulose in some rations by deer found by Maloiy, Kay, Goodall \& Topps (1970). Allo, Oh, Longhurst \& Connolly (1973) found that blacktailed deer (Dorcelaphus columbianus) and sheep showed similar patterns of volatile fatty acids in the rumen while Rogerson (1968) obtained similar coefficients of digestibility in cattle, eland and wildebeest. Likewise Arman (1969) found that digestibility determined with eland and Thomson's gazelle was only a fraction lower than that of cattle. Measurements on either the white-tailed deer (Dorcelaphus virginianus) (Ammann, Cowan, Mothershead \& Baumgardt, 1973) or the pronghorn antelope (Antilocapra americana) (Nagy \& Williams, 1969) on their own have indicated that digestion in these species is not greatly different from that in domestic ruminants.

\section{Growth of wild ruminants}

Information on both the normal and maximum rates of growth of wild ruminants is scarce. Only a few people have been able to study a sufficiently large number of animals for the results to represent the species as a whole. Bandy, Cowan \& Wood (1970) have examined four races of black-tailed deer, which were captured as fawns and reared on artificial diets. They found that all races, even when reared in a standard environment, and irrespective of sex, showed a seasonal periodicity in the pattern of growth, with losses of weight in winter. A similar phenomenon has been found in the red deer (R. N. B. Kay, personal communication). Von la Chevallerie \& Van Zyl (1971) were able to study the growth and development of the springbok under natural conditions by ear-tagging animals in the first week of life and subsequently cropping the herd at 4-weekly intervals. They found that both sexes grew relatively rapidly until they reached an age of 7 months and then their growth slowed. As a result they recommended that considerable cropping should take place at 7 months, which coincided well with a winter food shortage. 


\section{Carcass weight and composition}

The outstanding work of Ledger in East Africa (Ledger, Sachs \& Smith, 1967) and the studies of other people have provided a detailed knowledge of the carcasses of several wild ruminants. The carcass weight and dressing percentage of some of the more common wild ruminants found in Africa are given in Table 3. They illustrate the great diversity in both live weight and carcass weight of wild ruminants,

\section{Table 3. Carcass weight $(\mathrm{kg})$ and dressing percentage of species of wild ruminants}

\section{Species}

Giraffe (Giraffa camelopardalis)

Eland (Taurotragus oryx)

African buffalo (Syncerus caffer)

Kudu (Strepsiceros strepsiceros)

Waterbuck (Kobus ellipsiprymmus)

Wildebeest (Connochaetes taurinus)

Oryx (Oryx gazella)

Grant's gazelle (Gazella granti)

Impala (Aepyceros melampus)

Thomson's gazelle (Gazella thomsonii)

Duiker (Sylvicapra grimmia)

Steenbok (Raphiceros campestris)

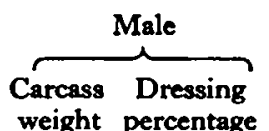

weight percentage

454

382

327

158

140

135

IOI

36

33

15

$9 \cdot 2$

6.I

$58 \cdot 6$
$66 \cdot 5$
$52 \cdot 2$
$66 \cdot 2$
$58 \cdot 6$
$55 \cdot 7$
$57 \cdot 0$
$60 \cdot 5$
$58 \cdot 1$
$58 \cdot 6$
$61 \cdot 2$
$63 \cdot 8$

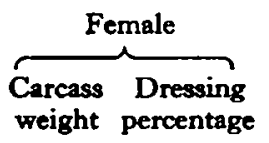

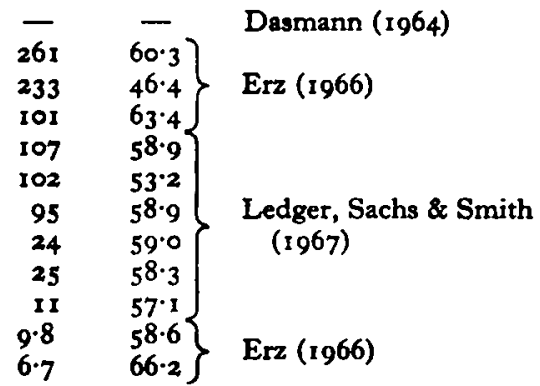

which may be useful when these animals are exploited further for meat production. Differences between sexes in carcass weights seem to be appreciable in some of the larger species only. The dressing percentages of all but the buffalo were 55 or above. These values are the same as or greater than those of fat, well-fed domestic ruminants. In the meat trade, different parts of the carcass or body differ in quality and economic value, and generally the best cuts are found in the hindquarters. Ledger and his colleagues have found that wildebeest, impala, Thomson's gazelle and Uganda kob have relatively heavy hindquarters, the weight being $58-59 \%$ of the total carcass. Conversely the comparable value for buffalo, which has heavy forequarters, is $44 \%$.

For both organoleptic and nutritional reasons there is a greater demand for meat which has a high lean content and the carcasses of wild ruminants appear to be especially suitable to meet this demand. Ledger et al. (1967) compared the carcass composition of several species with that of zebu cattle. For thin cows and bulls, the fat content of the carcass was $134-137 \mathrm{~g} / \mathrm{kg}$ while that for steers and fat cows was 286 and $329 \mathrm{~g} / \mathrm{kg}$ respectively. Wild ruminants had a fat content which varied between 18 and $70 \mathrm{~g} / \mathrm{kg}$. These low values were complemented by high contents of lean meat which varied from 770 to $830 \mathrm{~g} / \mathrm{kg}$, with the exception of the male buffalo which had a value of $740 \mathrm{~g} / \mathrm{kg}$. For zebu bulls and fat zebu cows the lean contents were 687 and $536 \mathrm{~g} / \mathrm{kg}$ respectively. In general the slaughtered wild ruminants were in good condition so in these species there appears to be very little propensity to deposit reserves of fat. If the meat of wild ruminants is to be widely 
accepted the cooking quality may need to be considered. Because it contains little fat the meat is less succulent than beef, and for some people's taste changes in conventional cooking procedures may need to be advocated. Ledger et al. (1967) and Von la Chevallerie (1972) recorded that the meat of several species was very palatable, but taste panels have shown a distinct preference for a few animals, e.g. the springbok.

\section{Conclusions}

It is apparent that our knowledge of the nutritional physiology of wild ruminants is inadequate for the prediction of their performance under either natural or modified conditions. However, they do have useful characteristics, such as their high lean content, which should encourage people to attempt a greater utilization of wild ruminants. At present, along with other ungulates and carnivores, they are an important part of a thriving tourist industry in several countries. The outstanding ability of some species to withstand adverse conditions may, in the near future, make them important producers of meat from areas which are not suitable for arable crops and which at present have a very low output of animal products from domesticated livestock.

\section{REFERENCES}

Allo, A. A., Oh, J. H., Longhurst, W. M. \& Connolly, G. E. (1973). F. Wildl. Mgmt 37, 202.

Ammann, A. P., Cowan, R. L., Mothershead, C. L. \& Baumgardt, B. R. (1973). F. Wildl. Mgmt $37,195$.

Arman, P. (1969). Surv. curr. Wildl. Res. Progr. E. Afr. no. 4.

Azavedo, J. C. S. \& Agnew, A. D. G. (1968). E. Afr. Wildl. F. 6, 145.

Bandy, P. J., Cowan, I. McT. \& Wood, A. J. (1970). Can. Y. Zool. 48, 1401.

Boeker, E. C., Scott, V. E., Reynolds, H. G. \& Donaldson, B. A. (1972). Y. Wildl. Mgmt 36, 56.

Brockway, J. M. \& Maloiy, G. M. O. (1968). J. Physiol., Lond. 194, 22 P.

Dasmann, R. F. (1964). African Game Ranching. Oxford: Pergamon Press.

du Plessis, S. S. (1972). Wildl. Monogr., Chestertown no. 30.

Erz, W. (1966). Z. Tierzücht. ZüchtBiol. 82, 348.

Field, C. R. (1968). Symp. zool. Soc. Lond. 2x, 135 .

Jarman, P. J. (1971). Oecologia 8, 157.

Kay, R. N. B., Maloiy, G. M. O. \& Goodall, E. D. (1968). Symp. zool. Soc. Lond. 21, ror.

Kiley, M. (1966). E. Afr. Wildl. F. 4, 153.

Ledger, H. P., Sachs, R. \& Smith, N. S. (1967). Wld Rev. Anim. Prod. 3, 13.

McEwan, E. H. \& Whitehead, P. E. (r970). Can. F. Zool. 48, 905.

McEwan, E. H. \& Whitehead, P. E. (1971). Can. F. Zool. 49, 443.

MacFarlane, W. V., Howard, B. \& Siebert, B. D. (1969). Nature, Lond. 221, $57^{8}$.

Maloiy, G. M. O., Kay, R. N. B., Goodall, E. D. \& Topps, J. H. (1970). Br. J. Nutr. $24,843$.

Mitchell, G. J. \& Smoliak, S. (197 I). f. Wildl. Mgmt 35, 238.

Nagy, J. G. \& Williams, G. L. (1969). F. Wildl. Mgmt 33, 437.

Nellis, C. H. \& Ross, R. L. (1969). J. Wildl. Mgmt 33, 191.

Rogerson, A. (1968). Symp. zool. Soc. Lond. 21, 153.

Roth, H. H. \& Osterberg, R. (1971). Rhod. 7. agric. Res. 9, 45.

Schmidt-Nielsen, K. (1964). Desert Animals. London: Oxford University Press.

Silver, H., Colovos, N. F. \& Hayes, H. H. (1959). F. Wildl. Mgmt 23, 434.

Silver, H., Colovos, N. F., Holter, J. B. \& Hayes, H. H. (1969). F. Wildl. Mgmt 33, 490.

Silver, H., Holter, J. B., Colovos, N. F. \& Hayes, H. H. (1971). F. Wildl. Mgmt 35, 37.

Skinner, J. D., Von la Chevallerie, M. \& Van Zyl, J. M. H. (1971). Anim. Breed. Abstr. $39,215$.

Smith, A. (1970). Proc. S. Afr. Soc. Anim. Prod. 9, 63.

Stewart, D. R. M. (1967). F. appl. Ecol. 4, 83.

Talbot, L. M. \& Talbot, M. H. (r963). F. Wildl. Mgmt r2, I3 1.

Taylor, C. R. (1968a). Symp. zool. Soc. Lond. 2r, 195.

Taylor, C. R. (1968b). Nature, Lond. 219, 18 I. 
Taylor, C. R. (1969). Scient. Am. 220, 88.

Taylor, C. R. \& Lyman, C. P. (1967). Physiol. Zool. 40, 280.

Taylor, C. R., Robertshaw, D. \& Hofmann, R. (1969). Am. J. Physiol. 217, 907.

Thompson, C. B., Holter, J. B., Hayes, H. H., Silver, H. \& Urban, W. E. (1973). J. Wildl. Mgmt 37, 301.

Treus, V. \& Kravchenko, D. (1968). Symp. zool. Soc. Lond. 2I, 395.

Von la Chevallerie, M. (1972). S. Afr. Y. Anim. Sci. 2, 10r.

Von la Chevallerie, M. \& Van Zyl, J. H. M. (1971). Agroanimalia 3, 115.

Wesley, D. E., Knox, K. L. \& Nagy, J. G. (1970). Y. Wildl. Mgmt 34, 908.

Wesley, D. E., Knox, K. L. \& Nagy, J. G. (1973). F. Wildl. Mgmt 37, 563.

Wilson, V. J. (1965). E. Afr. Wildl. J. 3, 27.

Wilson, V. J. (1966). Arnoldia, Rhod. 2 (14), I.

Wilson, V. J. (1969). Armoldia, Rhod. 59 (12), I.

Wilson, V. J. \& Child, G. (1964). Puku 2, I18.

Wilson, V. J. \& Child, G. (1965). Amoldia, Rhod. I (35), I. 